Journal of Rabbit Science, 32(1): 1-17 (2022)

\title{
IMPACT OF ALPINIA OFFICINARUM AND ZINC ON: 1- SOME BLOOD PARAMETERS, IMMUNITY AND ANTIOXIDANT STATUS IN CALIFORNIAN RABBIT BUCKS
}

\author{
M.E. El-Speiy; M.M. Abdella.; A.M. El-Kamhawy; and M.A. Abd-Elaal \\ Anim. Prod. Res. Instit., Agric. Res. Cent., Egypt. \\ e-mail: mohamed.elspeiy@yahoo.com
}

\begin{abstract}
Thirty six Californian male rabbits, 45 months age with average body weight of $2980 \pm 30.3 \mathrm{gm}$, were randomly divided into six treatments and used for the present study. The objective of this study was to investigate the influence of the dry powder from the rhizomes of Alpinia galanga (AGR) and zinc sulphate $\left(\mathrm{ZnSO}_{4}\right)$ supplementation on blood parameters, immunity and oxidative status of Californian rabbit bucks. All rabbits were fed on the basal diet, the $1^{\text {st }}$ group was served as control, $n d^{2}$ and $5^{\text {th }}$ groups and $3^{\text {rd }}$ and $6^{\text {th }}$ groups were fed basal diet supplemented with $1 \mathrm{~kg}$ and $2 \mathrm{~kg} / \mathrm{AGR} / \mathrm{ton}$ feed, respectively, while, $4^{\text {th }}, 5^{\text {th }}$ and $6^{\text {th }}$ groups were received $200 \mathrm{mg} \mathrm{Zn} / \mathrm{L}$ of drinking water for 60 days.

Results indicated that supplementation of AGR and $\mathrm{Zn}$ had the highest significant values of TP, Alb, AST and

$A L T$, whereas the control group had the lowest value. Significant improved of $\operatorname{IgG}$ in the groups supplemented with AGR2, Zn, AGR1+Zn and $A G R 2+Z n$. Groups of $Z n, A G R 1+Z n$ and $A G R 2+Z n$ recorded high significant value of IgM. Supplementation of AGR with or without Zn had significantly lower concentrations of TG, cholesterol and LDL compared to the control group. Significant increases were noticed in CAT, GSH, SOD, and TAC as compared with control one.

Conclusively, it is concluded that rabbit's bucks blood parameters, immunity and oxidative status may be improved with alpinia galanga and zinc supplementation to rations of Californian rabbit bucks.

Key words: Rabbits, blood parameters, Alpinia galanga, immunity, oxidative status.
\end{abstract}

\section{INTRODUCTION}

Medicinal plants and their derivatives are widely used in traditional societies around the world, and they are increasingly becoming popular in modernity as natural alternatives to synthetic chemicals Raviraja and Monisha 
(2015). Alpinia officinarum (AGR) is an important member of the Zingiberaceae family (Saboo et al., 2014). Tannins, alkaloids, flavonoids, vitamins and saponins are the important ingredients of AGR (Haghighian et al., 2015). Previous research has revealed that Alpinia galanga has a spectrum of pharmacological activities, including antibacterial, antifungal, antiviral, antiprotozoal, immunomodulatory, anti-oxidant (Sharma et al., 2018), antidiabetic, hypolipidemic, and many other pharmacological effects (Kiuchi et al., 2002;. Chouni and Paul, 2018). Alpinia officinarum could have been a great source of free radical scavengers in nature (Kim et al., 1997).

Trace elements, especially zinc, are important for health and immunity, even though they are generally required in trace quantities. They play a role in the evolution, reproduction, and growth. Trace elements function as cofactors for enzymes that are vital for animal immunity (Aksu et al., 2012). Important enzymes that do use trace elements as cofactors comprise superoxide dismutase, glutathione reducatase, glutathione peroxidase, thioredoxinreeducates, ceruloplasmin, and catalase. These enzymes serve as antioxidants, avoiding oxidative stress by mitigating oxidants synthesized in response to specific stimuli. Moreover, trace minerals contribute to an animal's general wellbeing, increasing disease resistance. Trace elements are required for the normal functioning of a variety of enzymes and proteins that are engaged in a variety of physiological, biochemical, and metabolic processes that contribute in growth and production (Yatoo et al., 2013). Trace elements, in principle, promote immunological response and productivity (Terpilowska and Siwicki, 2011).

Therefore, impact of alpinia officinarum and zinc on: 1- some blood parameters, immunity and antioxidant status in Californian rabbit bucks.

\section{MATERIALS AND METHODS}

\section{Housing and management:}

From December till February (winter season), the current study was carried out in a private rabbitry farm in Qalubia governorate, Egypt. The researchers aimed to study the impacts of Alpinia galanga and zinc sulphate $\left(\mathrm{ZnSO}_{4}\right)$ supplementation on blood parameters of Californian rabbit bucks. Thirty six Californian male rabbits, 4-5 months age with average body weight of $2980 \pm 30.3$ gm, were randomly distributed into six treatments (6 individual each) were used. Rabbits were housed in wire galvanized batteries approximately $60 \times 55 \times 40 \mathrm{~cm}$ in a naturally ventilated container. Pellet feeders and automatic drinkers were fitted in the batteries. The basal experimental ration was formulated and pelleted to 


\section{IMPACT OF ALPINIA OFFICINARUM AND ZINC ON RABBIT BUCKS 3}

cover the nutrient requirements of rabbits according to NRC, (1977), as shown in Table 1.

Table 1. The composition and chemical analysis of the basal experimental diet

\begin{tabular}{|c|c|c|c|c|c|}
\hline Ingredients & $\%$ & \multicolumn{4}{|c|}{ Calculated analysis } \\
\hline Yellow corn & 6.22 & \multicolumn{3}{|c|}{ Crude protein, $\%$} & 18.8 \\
\hline Soybean meal, 44\% & 22.33 & \multicolumn{3}{|c|}{ Crude fiber, $\%$} & 13.0 \\
\hline Wheat bran & 23.33 & \multicolumn{3}{|l|}{ Ether extract, \% } & 3.0 \\
\hline Barley & 15.00 & \multicolumn{3}{|c|}{ Digestible energy (kcal/kg diet) } & 2680 \\
\hline Alfalfa hay & 30.12 & \multicolumn{3}{|c|}{$\mathrm{n}-6$ poly unsaturated FAs $\%$} & 0.3 \\
\hline \multirow[t]{2}{*}{ Ground limestone } & 1.00 & \multicolumn{3}{|c|}{ n-3 poly unsaturated $\mathrm{FAs} \%$} & 1.03 \\
\hline & & \multicolumn{3}{|c|}{ Zn, ingredients +Premix (50+50mg) } & 100 \\
\hline Dicalcium Phosphate & 1.20 & \multicolumn{4}{|c|}{ Determined analysis (g/kg diet) } \\
\hline Common salt & 0.50 & Dry matter & 897.1 & Crude fiber & 138.5 \\
\hline Vit. + min. premix ${ }^{*}$ & 0.30 & Organic matter & 801.4 & Ether extract & 26.2 \\
\hline Total & 100.00 & Crude protein & 169.8 & Nitrogen-free extract & 575.0 \\
\hline & & & & Ash & 87.9 \\
\hline
\end{tabular}

*Each $3 \mathrm{~kg}$ of premix contains: Vit. A: 12,000,000 IU; Vit. $\mathrm{D}_{3}$ : 3,000,000 IU; Vit. E: $10.0 \mathrm{mg}$; Vit. $\mathrm{K}_{3}: 3.0 \mathrm{mg}$; Vit. $\mathrm{B}_{1}: 200 \mathrm{mg}$ : Vit. $\mathrm{B}_{2}: 5.0 \mathrm{mg}$ Vit. $\mathrm{B}_{6}: 3.0 \mathrm{mg}$ : Vit. $\mathrm{B}_{12}: 15.0 \mathrm{mg}$; Biotin: $50.0 \mathrm{mg}$; Folic acid: $1.0 \mathrm{mg}$; Nicotinic acid: $35.0 \mathrm{mg}$ : Pantothenic acid: $10.0 \mathrm{mg}$; Mn: $80 \mathrm{~g}$; Cu: $8.8 \mathrm{~g}$; Zn: 50 $\mathrm{g} ; \mathrm{Fe}: 35 \mathrm{~g} ; \mathrm{I}: 1 \mathrm{~g} ; \mathrm{Co}: 0.15 \mathrm{~g}$ and Se: $0.3 \mathrm{~g}$.

Materials plant: A dried AGR was purchased in Alexandria at a local market. Supplements of AGR powder were added to feeds as 1 or $2 \mathrm{~kg} /$ ton feed for groups ( 2 and 5) and (3 and 6), respectively, based on a dose 50 or $100 \mathrm{mg} / \mathrm{kg}$ body weight for each buck/day/2 month; according to Sarieh et al., (2014).

Chemical: Zinc sulfate is an inorganic compound and used as a dietary supplement to treat zinc deficiency, formula: $\mathrm{ZnSO}_{4}$, molar mass: $161.47 \mathrm{~g} / \mathrm{mol}$, soluble in water, were purchased from El-Gomhoria Company for chemical, Drugs and Medical Instruments, Alex, Egypt.

Kits: Biochemical analysis kits were purchased from Biodiagnostic Company for Pharmaceutical and Chemicals in Dokki, Egypt. For biochemical analysis, Spectrophotometers GNW-Model: SM-721, Absorbance Microplate Readers, and other laboratory equipment assistance were employed.

\section{Chemical analysis:}

Analysis of Alpinia galanga rhizomes were done in Alexandria, Egypt's City of Scientific Research and Technological Applications. The GCMS-QP 2010 system (Shimadzu, Japan) was utilized to determine the components of the Khella extract using mass spectrometry and gas chromatography (GC-MS). The sample 
was injected through a Rtx-5MS column at a rate of $0.9 \mathrm{mLmin}-1$ at $260^{\circ} \mathrm{C}$ using helium as a carrier $(30 \mathrm{~m} 0.25 \mathrm{~mm}, 0.25 \mathrm{~m}$ thick). The oven temperature was set to $61^{\circ} \mathrm{C}$ and the split injection mode was set at 50:1. At a 70 e Vionisation potential, the ion source temperature was $230^{\circ} \mathrm{C}$, whereas the interface temperature was $250^{\circ} \mathrm{C}$. Based on their rate, the extract contents were identified using the NIST11library (Gaithersburg, USA).

Experimental design was as follows:

Group 1: basal diet and served as control ( C )

Group 2: basal diet $+1 \mathrm{~kg} / \mathrm{AGR} /$ ton feed (AGR1)

Group 3: basal diet $+2 \mathrm{~kg} / \mathrm{AGR} / \mathrm{ton}$ feed (AGR2)

Group4: basal diet $+200 \mathrm{mg} \mathrm{Zn/L}$ drinking water $(\mathbf{Z n})$

Group 5: basal diet+1 kg/AGR/ton feed AGR1+200 mg Zn/L water (AGR1+Zn)

Group 6: basal diet+2 kg/AGR/ton feed AGR2 +200 mg Zn/L water (AGR2+Zn)

$* *$ Rabbits fed ad libitum basal diet containing $50 \mathrm{mg}$ zinc/ $\mathrm{kg}$ diet $/$ premix source $+50 \mathrm{mg} / \mathrm{kg}$ diet/ ingredient diet.

\section{Blood samples:}

At the end of the experiment, before accessing feed and water, blood samples were withdrawn from marginal ear veins under vacuuming in clean tubes with heparin in the morning (8.00:9.00 am) for each treatment group. Blood plasma was obtained by centrifuging the blood for 20 minutes at $3500 \mathrm{rpm}$ and then storing it at $-20^{\circ} \mathrm{C}$ for later analysis.

\section{Blood biochemical constituents:}

Total plasma protein (TP), and albumin (Alb) were measured by the methods described by Doumas et al., (1981); globulin) Glo) was calculated. Cholesterol, aspartate aminotransferase (AST), and alanine aminotransferase (ALT) were determined according to (Reitman and Frankel, 1957); triglycerides (TG) was assessed according to (Fasati and Prencipe, 1982), however, highdensity lipoprotein (HDL), low-density lipoprotein (LDL) were calculated using the formula:

LDL-c, (mg/dl =Total cholesterol-\{HDL-c+(TG/5)\}), which explained by William et al., (1972).

\section{Immune response and antioxidant status determination:}

Different types of immunoglobulins in plasma (IgG and $\operatorname{IgM}$ ) were determined using commercial ELISA kits. The antioxidant effectiveness was determined by measuring lipid peroxidation, enzymatic antioxidant status in 
IMPACT OF ALPINIA OFFICINARUM AND ZINC ON RABBIT BUCKS 5

plasma, catalase (CAT), reduced glutathione (GSH) and glutathione peroxidase (GPx) (Sanja et al., 2015). According to Ippoushi et al., (2005), total antioxidant capacity (TAC) and malonaldehyde (MDA) were measured.

Sheep red blood cells (SRBC)-induced delayed type hypersensitivity reaction (DTH):

Footpad edoema was used as an indicator for delayed type hypersensitivity response to assess the influence of extracts on antigenspecific cellular immunity. To challenge with SRBC, on day 0, all of the groups were immunised by injection of $1 \mathrm{ml}$ of SRBC cell suspension into the right hind foot pad, which was equivalent to 5109 SRBC per ml, on day 15 , all groups received a challenge, which comprised of injecting by $0.5 \mathrm{ml}$ of SRBC cell suspension subcutaneously into the left hind foot pad, and evaluating the thickness of the left hind foot pad with a plethysmometer after 24, 48, and 72 hours.

The difference in $\mathrm{Cm}$ between the thickness of the left hind foot before and after the challenge was used to estimate DTH (Lagrange et al., 1974).

\section{Statistical analysis:}

All data were subjected to analysis of variance as described in SAS Program (SAS, 2002).

The significant means differences among groups were separated by Duncan's multiple rang test (Duncan, 1955).

\section{RESULTS AND DISCUSSION}

Analysis of Alpinia officinarum:

Alpinia officinarum had considerably greater total phenols (12.34 $\mathrm{mg} / \mathrm{g} \mathrm{DM}$ ), while carotenoids, total flavonoids, tannins, and saponins were $0.57,6.22,2.16$, and $0.27 \mathrm{mg} / \mathrm{g}$ DM, respectively (Tables 2 and 3). Alpinia officinarum includes bioactive components as well as antioxidant qualities, according to current research. These findings are in line with those of Abdullah et al., (2015), Basri et al., (2017), and Rachkeeree et al., (2018), who revealed that Alpinia officinarum has more bioactive components such flavonoids, phenolic acids, and alkaloids, as well as, flavones such galangin, alpinin, and kaempferol.

\section{1- Impact of Alpinia galanga (AGR) and Zn on some biochemical blood parameters:}

Table 4 shows the effect of dietary AGR with or without $\mathrm{Zn}$ on biochemical blood plasma. In comparison to the other groups, the groups supplemented with 
AGR1, Zn, AGR1+Zn, and AGR2+Zn had the highest significant values of TP and $\mathrm{Alb}$, whereas the control group had the lowest value for the previous

Table 2. The total concentration of major bioactive components identified in Alpinia galanga (AGR) on dry matter bases.

\begin{tabular}{|c|c|c|c|c|}
\hline \multicolumn{5}{|c|}{ Alpinia galanga rhizome (AGR) mg/g DM } \\
\hline Total phenols & Carotenoids & Total flavonoids & Tannins & Saponins \\
\hline 12.34 & 0.57 & 6.22 & 2.16 & 0.27 \\
\hline
\end{tabular}

Table 3. Chemical constituents identified by gas chromatography and mass spectrometry

\begin{tabular}{|c|l|c|c|c|}
\hline $\begin{array}{c}\text { Pea } \\
\text { ks }\end{array}$ & \multicolumn{1}{|c|}{ Compounds } & $\begin{array}{c}\text { Retention } \\
\text { time (min)a }\end{array}$ & $\begin{array}{c}\text { Peak area } \\
(\mathbf{\%})\end{array}$ & $\begin{array}{l}\text { Molecula } \\
\text { r formula }\end{array}$ \\
\hline 1 & Glycyl-D-asparagine & 4.138 & 50.21 & $\mathrm{C} 6 \mathrm{H} 11 \mathrm{~N} 3 \mathrm{O} 4$ \\
\hline 2 & Benzenepropanal & 9.051 & 37.35 & $\mathrm{C} 9 \mathrm{H} 100$ \\
\hline 3 & 3-phenyl-2-butanone & 11.880 & 20.49 & $\mathrm{C} 10 \mathrm{H} 12 \mathrm{O}$ \\
\hline 4 & Eucalyptol & 5.470 & 13.89 & $\mathrm{C} 10 \mathrm{H} 18 \mathrm{O}$ \\
\hline 5 & Pyranone & 9.174 & 7.743 & $\mathrm{C} 6 \mathrm{H} 8 \mathrm{O} 4$ \\
\hline 6 & $\alpha$-Terpineol & 10.519 & 9.09 & $\mathrm{C} 10 \mathrm{H} 180$ \\
\hline 7 & Fenchyl acetate & 11.508 & 5.44 & $\mathrm{C} 12 \mathrm{H} 20 \mathrm{O} 2$ \\
\hline 8 & 5-Hydroxymethylfurfural & 12.840 & 11.28 & $\mathrm{C} 6 \mathrm{H} 6 \mathrm{O} 3$ \\
\hline 9 & Cinnamic acid & 17.957 & 3.82 & $\mathrm{C} 9 \mathrm{H} 8 \mathrm{O} 2$ \\
\hline 10 & Thymol & 21.19 & 25.25 & $\mathrm{C} 10 \mathrm{H} 140$ \\
\hline 11 & Carotol & 25.894 & 17.44 & $\mathrm{C} 15 \mathrm{H} 260$ \\
\hline 12 & Palmitic acid & 39.062 & 4.26 & $\mathrm{C} 16 \mathrm{H} 32 \mathrm{O} 2$ \\
\hline
\end{tabular}

treatments and the greatest concentrations of AST and ALT. In comparison to the control group, AST and ALT concentrations were low in the same groups. Globulin was recorded unsatisfactory levels in all groups.

Due to the presence of various bioactive components, Alpinia galanga is well-known as a medicinal herbal in several traditional methods of treating a wide variety of diseases. Our findings are in agreement with Ganguly et al., (2002), who found that increasing TP and Alb concentrations indicate AGR's function in improving liver efficiency. Given the total bioactive compounds such as phenols, total flavonoids, and antioxidant activity content of Alpinia species, this bioactive component has a significant impact on the liver and kidney in animals, resulting 


\section{IMPACT OF ALPINIA OFFICINARUM AND ZINC ON RABBIT BUCKS 7}

in a reduction in liver function enzymes (ALT and AST) in rats (Negm and Ragheb, 2019). On the other hand, Abdel-Azeem and Basyony (2019) found that

Table 4. Effect of supplemented diet with Alpinia officinarum and $\mathrm{Zn}$ on some biochemical blood parameters of Californian rabbit bucks

\begin{tabular}{|c|c|c|c|c|c|}
\hline \multirow[t]{2}{*}{ Treatment } & \multicolumn{5}{|c|}{ Parameters } \\
\hline & $\mathrm{TP},(\mathrm{g} / \mathrm{dl})$ & Alb, (g/dl) & Glo, (g/dl) & AST, (U/L & ALT, (U/L) \\
\hline $\mathbf{C}$ & $6.58^{\mathrm{c}}$ & $3.65^{b}$ & 2.93 & $34.26^{\mathrm{a}}$ & $34.42^{\mathrm{a}}$ \\
\hline $\mathbf{A G R}_{1}$ & $7.29^{b}$ & $4.44^{\mathrm{b}}$ & 2.85 & $25.31^{\mathrm{b}}$ & $28.45^{\mathrm{b}}$ \\
\hline $\mathbf{A G R}_{2}$ & $7.37^{\mathrm{a}}$ & $4.71^{\mathrm{a}}$ & 2.63 & $26.21^{\mathrm{b}}$ & $26.35^{\mathrm{b}}$ \\
\hline $\mathbf{Z n}$ & $7.41^{\mathrm{a}}$ & $4.83^{\mathrm{a}}$ & 2.58 & $25.41^{b}$ & $26.44^{b}$ \\
\hline $\mathrm{AGR}_{1}+\mathrm{Zn}$ & $7.42^{\mathrm{a}}$ & $4.89^{\mathrm{a}}$ & 2.53 & $25.0^{\mathrm{b}}$ & $25.7^{\mathrm{b}}$ \\
\hline $\mathrm{AGR}_{2}+\mathrm{Zn}$ & $7.61^{\mathrm{a}}$ & $5.29^{\mathrm{a}}$ & 2.32 & $23.7^{b}$ & $27.0^{b}$ \\
\hline SEM & 0.34 & 0.18 & 0.21 & 1.16 & 1.79 \\
\hline P-value & $<.0021$ & $<.0011$ & 0.643 & $<.0031$ & $<.0034$ \\
\hline
\end{tabular}

** a-d: Means with different superscripts within the same column differ significantly at $(\mathrm{P} \leq 0.05)$.

C: Control. AGR1: Alpinia galanga powder in diet as $50 \mathrm{mg} / \mathrm{kg}$ BW, AGR2: Alpinia galanga powder in diet as $100 \mathrm{mg} / \mathrm{kg} \mathrm{BW}, \mathrm{Zn}$ : 200mg Zn/litter of drinking water, AGR1+Zn= Alpinia galanga powder in diet as $50 \mathrm{mg} / \mathrm{kg} \mathrm{BW}+200 \mathrm{mg} \mathrm{Zn} /$ litter of drinking water, AGR2 $+\mathrm{Zn}=$ Alpinia galanga powder in diet as $100 \mathrm{mg} / \mathrm{kg} \mathrm{BW}+200 \mathrm{mg} \mathrm{Zn} /$ litter of drinking water, TP: Total protein, Alb: Albumin, Glo: Globulin, AST: Aspartate aminotransferase, ALT: Alanine aminotransferase.

plasma Glo, Alb, and TP levels were significantly higher in chicks who consumed a diet enriched with Alpinia extract.

Regarding role of $\mathrm{Zn}$, our results are harmonize with results obtained by Ahmed et al., (2020) who showed that the rabbit consumed nano-zinc oxide significantly improved serum ALT, AST, urea, and creatinine. Also, Boiko et al., (2020) recorded that the weaning rabbit drinking different level of zinc citrate affect the content of the TP and activity of liver enzymes in the blood of the experimental groups. It has to be renowned that the greatest effect was exerted on level of TP and activity of ALT, alkaline phosphatase enzymes in animals that consumed the smallest amount of zinc citrate.

\section{2- Impact of Alpinia galanga (AGR) and Zn on immunity status:}

The results presented in Table 5 showed a significant improvement of $\mathrm{IgG}$ in the groups supplemented with AGR2, Zn, AGR1+Zn and AGR2+Zn. While, groups $\mathrm{Zn}, \mathrm{AGR} 1+\mathrm{Zn}$ and AGR2+Zn recorded highly significant differences of IgM. On the other hand, groups AGR1+Zn and AGR2+Zn showed improved of SRBS antigen compared to the control group. Harmony with our results, Flavonoids discovered in Alpinia galanga exhibit strong immunological 
stimulating effects in mice, as well as an effect on antibody production to Tdependent antigen SRBCs, which requires the cooperation of T-lymphocytes and macrophages (Alok et al., 2012). Alpinia galanga contains many bioactive Table 5. Effect of supplemented diet with AGR and $\mathrm{Zn}$ on immune response in the blood plasma of Californian rabbit bucks

\begin{tabular}{|c|c|c|c|}
\hline \multirow{2}{*}{ Treatment } & \multicolumn{3}{|c|}{ Parameters } \\
\cline { 2 - 4 } & IgG & IgM & SRBS /reaction index \\
\hline $\mathbf{C}$ & $158.13^{\mathrm{c}}$ & $51.43^{\mathrm{c}}$ & 0.00 \\
\hline AGR $_{\mathbf{1}}$ & $188.22^{\mathrm{b}}$ & $65.89^{\mathrm{b}}$ & $38.2^{\mathrm{c}}$ \\
\hline $\mathbf{A G R}_{\mathbf{2}}$ & $211.43^{\mathrm{a}}$ & $63.39^{\mathrm{b}}$ & $44.7^{\mathrm{b}}$ \\
\hline $\mathbf{Z n}$ & $215.17^{\mathrm{a}}$ & $69.19^{\mathrm{a}}$ & $14.2^{\mathrm{d}}$ \\
\hline $\mathbf{A G R}_{\mathbf{1}}+\mathbf{Z n}$ & $205.57^{\mathrm{a}}$ & $70.68^{\mathrm{a}}$ & $65.6^{\mathrm{a}}$ \\
\hline AGR $_{\mathbf{2}}+\mathbf{Z n}$ & $212.13^{\mathrm{a}}$ & $73.51^{\mathrm{a}}$ & $71.10^{\mathrm{a}}$ \\
\hline SEM & $\mathbf{3 . 2 5 5}$ & $\mathbf{0 . 1 3 2}$ & $\mathbf{2 . 4 5}$ \\
\hline P-value & $<.0029$ & $<.0034$ & $<.0045$ \\
\hline
\end{tabular}

** a-d: Means with different superscripts within the same column differ significantly at $(\mathrm{P} \leq 0.05)$. C: Control. AGR1: Alpinia galanga powder in diet as $50 \mathrm{mg} / \mathrm{kg}$ BW, AGR2: Alpinia galanga powder in diet as $100 \mathrm{mg} / \mathrm{kg} \mathrm{BW}, \mathrm{Zn}$ : 200mg Zn/litter of drinking water, AGR1+Zn= Alpinia galanga powder in diet as $50 \mathrm{mg} / \mathrm{kg} \mathrm{BW}+200 \mathrm{mg} \mathrm{Zn} / \mathrm{litter}$ of drinking water, AGR2 $+\mathrm{Zn}=$ Alpinia galanga powder in diet as $100 \mathrm{mg} / \mathrm{kg} \mathrm{BW}+200 \mathrm{mg} \mathrm{Zn/litter} \mathrm{of} \mathrm{drinking} \mathrm{water.} \mathrm{IgG}=$ immunoglobulin G,IgM=: Immunoglobulin M. sheep red blood cell (SRBC): Delayed type hypersensitivity response to SRBC was induced in mice.

component such as tannins, alkaloids, flavonoids, vitamins and saponins are the important ingredients, this component have immunomodulatory activity due to down-regulated chemokine expression (CXCL1, CCL4, CCL5, CXCL5, CXCL10) and cytokines (IL-6, IL-10, IL-1 $\beta$, IL-12p70, TNF, IL-1 $\alpha$ ) (W Zeng et al., 2018), immunostimulants activity by stimulating mononuclear cells to secrete cytokine IL-1 $\beta$, IFN- $\gamma$, and TNF- $\alpha$ (Liao et al., 2015).

Regarding to the role of $\mathrm{Zn}$, Haase et al., (2007); Hassan et al., (2017) recorded that zinc has a vital part in the transcription of polynucleotides and the expression of genes in cells, as well as in the activation of humoral and cellular immune factors. Also, Ezzat et al., (2019) reported that diet supplemented with zinc methionine improved serum IgG and $\operatorname{IgM}$ were augmented significantly in supplemented groups compared with the control. Also, zinc has an effect on thymulin secretion by the thymus gland, which increases T-cell production. As a result of the zinc deficit, the thymus misfired, affecting normal immunological function significantly (Mocchegiani et al., 1998). However, another study by Li et al., (2016) recorded that consumed nano zinc ( $\mathrm{nZnO}$ ) or $\mathrm{ZnO}$ supplementation of weanling piglet diets increased $\gamma-$ globulin and $\mathrm{IgG}$. 
IMPACT OF ALPINIA OFFICINARUM AND ZINC ON RABBIT BUCKS 9

\section{3- Impact of AGR and Zn on lipid profile:}

Table 6 shows that all groups using AGR with or without $\mathrm{Zn}$ had significantly lower concentrations of TG, cholesterol and LDL, while HDL-c and

Table 6. Effect of supplemented diet with AGR and Zn on lipid profile in blood of Californian rabbit bucks

\begin{tabular}{|l|c|c|c|c|}
\hline \multirow{2}{*}{ Treatment } & \multicolumn{4}{|c|}{ Parameters } \\
\cline { 2 - 5 } & TG, mg/dl & TC, $\mathbf{~ m g / d l ~}$ & HDL-c, $\mathbf{~ m g / d l}$ & LDL-c, mg/dl \\
\hline $\mathbf{C}$ & $96.81^{\mathrm{a}}$ & $88.27^{\mathrm{a}}$ & $32.52^{\mathrm{b}}$ & $36.39^{\mathrm{a}}$ \\
\hline AGR $_{\mathbf{1}}$ & $78.10^{\mathrm{bc}}$ & $77.34^{\mathrm{b}}$ & $44.13^{\mathrm{a}}$ & $17.59^{\mathrm{b}}$ \\
\hline AGR $_{\mathbf{2}}$ & $74.18^{\mathrm{b}}$ & $74.24^{\mathrm{b}}$ & $43.21^{\mathrm{a}}$ & $16.19^{\mathrm{b}}$ \\
\hline $\mathbf{Z n}$ & $72.74^{\mathrm{b}}$ & $71.44^{\mathrm{b}}$ & $41.92^{\mathrm{a}}$ & $14.19^{\mathrm{b}}$ \\
\hline $\mathbf{A G R}_{\mathbf{1}}+\mathbf{Z n}$ & $72.54^{\mathrm{b}}$ & $70.98^{\mathrm{b}}$ & $42.44^{\mathrm{a}}$ & $14.03^{\mathrm{b}}$ \\
\hline $\mathbf{A G R}_{\mathbf{2}}+\mathbf{Z n}$ & $71.32^{\mathrm{b}}$ & $71.23^{\mathrm{b}}$ & 43.48 & $13.49^{\mathrm{b}}$ \\
\hline SEM & $\mathbf{2 . 2 9}$ & $\mathbf{1 . 4 9}$ & $\mathbf{2 . 8 9}$ & $\mathbf{1 . 7 4}$ \\
\hline P-value & $<.0042$ & $<.0022$ & $<.0045$ & $<.0035$ \\
\hline
\end{tabular}

** a-d: Means with different superscripts within the same column differ significantly at $(\mathrm{P} \leq 0.05)$.

C: Control. AGR1: Alpinia galanga powder in diet as $50 \mathrm{mg} / \mathrm{kg}$ BW, AGR2: Alpinia galanga powder in diet as $100 \mathrm{mg} / \mathrm{kg} \mathrm{BW}, \mathrm{Zn}$ : 200mg Zn/litter of drinking water, AGR1+Zn= Alpinia galanga powder in diet as $50 \mathrm{mg} / \mathrm{kg} \mathrm{BW}+200 \mathrm{mg} \mathrm{Zn} /$ litter of drinking water, AGR2 $+\mathrm{Zn}=$ Alpinia galanga powder in diet as $100 \mathrm{mg} / \mathrm{kg} \mathrm{BW}+200 \mathrm{mg} \mathrm{Zn/litter} \mathrm{of} \mathrm{drinking} \mathrm{water,} \mathrm{TG:} \mathrm{Total} \mathrm{glycerids,}$ TC: Total cholesterol, HDL-c: High density lipoprotein, LDL-c: Low density lipoprotein.

TAC were significantly increased compared to the control group. These findings are consistent with those of Kaushik et al., (2013), who discovered that the AGR extract reduced total cholesterol, TG and LDL while, increasing HDL. Furthermore, Abdel-Azeem and Basyony (2019) found that supplementing a diet with Alpinia galangal extract (AGRE) significantly reduced plasma total cholesterol, TG, LDL, and total lipids. Considerable, Negm and Ragheb (2019) found that supplementing AGRE led at drop in blood lipid profiles TG and TC, as well as a large increase in HDL-c. Our findings were agree with Kumar and Alagawadi's (2013) which revealed that galangin enhanced liver function and serum lipid profile. According to Janten et al., (2005) who found that the rhizomes of Alpinia officinarum lowered serum TG and TC while increasing serum HDL levels in mice. Regarding to the role of zinc, the findings of this study agree with those of Boiko et al., (2020), who discovered that supplementing drinking water of rabbits with nano-zinc citrate reduced cholesterol, TG, and lipid hydroperoxides. Interestingly, Xu et al., (2015) who emphasized that in lipid disturbance rabbits, zinc protected the liver, decreased TG, and elevated HDL-C. In vivo, zinc inhibited the expression of matrix metalloprotease 2 (MMP2) and matrix metalloprotease 9 (MMP9). 


\section{4- Impact of AGR and Zn on antioxidant status:}

The effect of AGR and Zn on antioxidant capacity was summarized (Table 7) as significant increases in CAT, GSH, SOD, and TAC while diminishing MDA Table 7. Effect of supplemented diet with AGR and $\mathrm{Zn}$ on antioxidant status in blood of Californian rabbit bucks

\begin{tabular}{|c|c|c|c|c|c|}
\hline \multirow{2}{*}{ Treatment } & \multicolumn{5}{|c|}{ Parameters } \\
\cline { 2 - 6 } & $\begin{array}{c}\mathbf{C A T}, \\
\boldsymbol{\mu m o l} / \mathbf{m l}\end{array}$ & $\begin{array}{c}\mathbf{G S H}, \\
\boldsymbol{\mu m o l} / \mathbf{m l}\end{array}$ & $\begin{array}{c}\mathbf{S O D},(\boldsymbol{\mu} \\
/ \mathbf{d l})\end{array}$ & $\begin{array}{c}\text { TAC, } \\
\boldsymbol{\mu m o l} / \mathbf{m l}\end{array}$ & $\begin{array}{c}\text { MDA, } \\
\mathbf{n m o l} / \mathbf{m l}\end{array}$ \\
\hline $\mathrm{C}$ & $13.13^{\mathrm{c}}$ & $13.29^{\mathrm{c}}$ & $16.11^{\mathrm{b}}$ & $1.26^{\mathrm{c}}$ & $5.97^{\mathrm{a}}$ \\
\hline $\mathrm{AGR}_{1}$ & $15.95^{\mathrm{b}}$ & $15.12^{\mathrm{b}}$ & $17.60^{\mathrm{b}}$ & $1.73^{\mathrm{ab}}$ & $4.68^{\mathrm{b}}$ \\
\hline $\mathrm{AGR}_{2}$ & $16.94^{\mathrm{b}}$ & $17.76^{\mathrm{b}}$ & $17.62^{\mathrm{b}}$ & $1.95^{\mathrm{ab}}$ & $4.32^{\mathrm{b}}$ \\
\hline $\mathrm{Zn}$ & $15.88^{\mathrm{b}}$ & $16.58^{\mathrm{b}}$ & $16.89^{\mathrm{b}}$ & $1.88^{\mathrm{a}}$ & $4.01^{\mathrm{b}}$ \\
\hline $\mathrm{AGR}_{1}+\mathrm{Zn}$ & $19.86^{\mathrm{a}}$ & $21.85^{\mathrm{a}}$ & $19.82 \mathrm{a}$ & $1.95^{\mathrm{a}}$ & $3.37^{\mathrm{c}}$ \\
\hline $\mathrm{AGR}_{2}+\mathrm{Zn}$ & $21.41^{\mathrm{a}}$ & $22.12^{\mathrm{a}}$ & $20.12 \mathrm{a}$ & $1.99^{\mathrm{a}}$ & $3.54^{\mathrm{c}}$ \\
\hline SEM & $\mathbf{0 . 8 6}$ & $\mathbf{0 . 9 2}$ & $\mathbf{0 . 8 9}$ & $\mathbf{0 . 5 4}$ & $\mathbf{0 . 7 4}$ \\
\hline P-value & $<.0083$ & $<.0047$ & $<.0048$ & $<.0023$ & $<.0032$ \\
\hline
\end{tabular}

** a-d: Means with different superscripts within the same column differ significantly at $(\mathrm{P} \leq 0.05)$.

C: Control. AGR1: Alpinia galanga powder in diet as $50 \mathrm{mg} / \mathrm{kg}$ BW, AGR2: Alpinia galanga powder in diet as $100 \mathrm{mg} / \mathrm{kg} \mathrm{BW}, \mathrm{Zn}$ : $200 \mathrm{mg} \mathrm{Zn/litter} \mathrm{of} \mathrm{drinking} \mathrm{water,} \mathrm{AGR1+Zn=} \mathrm{Alpinia}$ galanga powder in diet as $50 \mathrm{mg} / \mathrm{kg} \mathrm{BW}+200 \mathrm{mg} \mathrm{Zn} /$ litter of drinking water, AGR2 $+\mathrm{Zn}=$ Alpinia galanga powder in diet as $100 \mathrm{mg} / \mathrm{kg} \mathrm{BW}+200 \mathrm{mg} \mathrm{Zn/litter} \mathrm{of} \mathrm{drinking} \mathrm{water.CAT:} \mathrm{Catalase,}$ GSH :Reduced glutathione, SOD: Superoxide dismutase, TAC: Total antioxidant capacity .MDA: Malonylaldehyed.

in the AGR1+Zn and AGR2+Zn supplemented groups. While, the groups treated with AGR1, AGR2, and Zn showed no significant differences, the similar trend was observed for CAT, GSH, SOD, TAC, and MDA at all parameters measured, however, are improved was noticed in the experimental groups than in the control one. Previous study are agree in our results by Mahae and Chaiseri (2009) who recorded that the highest significant activity levels of SOD and GPx concentration detected in group supplemented with galanga may be due to the which considers a rich source of antioxidants that lead to the expulsion of toxins and inhibiting free radicals. Also, recent studies and agree with our result by Abdel-Azeem and Basyony (2019) who found that supplementing a diet with Alpinia galanga exetract (AGRE) significantly raised antioxidant capacity, glutathione Stransferase, superoxide dismutase, catalase, and glutathione peroxidase Likewise. Negm and Ragheb (2019) found that supplementing AGRE increased SOD levels while decreasing MDA levels. Also, Al-Mosawy and Khalid (2021) who documented that the highest significant activity level of SOD and GPx and 


\section{IMPACT OF ALPINIA OFFICINARUM AND ZINC ON RABBIT BUCKS 11}

reduced reversed the $\mathrm{H}_{2} \mathrm{O}_{2}$ impacts recorded in group consumed Alpinia galanga extract in quails.

Regarding, the role of zinc, the findings of this study agree with those Boiko et al., (2020) who revealed that increasing glutathione reductase and catalase activity. Also, Mazani et al., (2012) found that $\mathrm{Zn}$ supplementation boosted overall antioxidant capacity, glutathione peroxidase, and SOD activity while decreasing MDA levels in the blood serum. On the other hand, Alissa et al., (2009) illustrated that dietary zinc supplementation can modulate SOD activity in rabbits. In addition, Zhao et al., (2014) found that the concentration of SOD was significantly increased in serum of broilers after feeding $\mathrm{nZnO}$. in the AGR1+Zn and AGR2+Zn supplemented groups. While, the groups treated with AGR1, AGR2, and Zn showed no significant differences, the similar trend was observed for CAT, GSH, SOD, TAC, and MDA at all parameters measured, however, are improved was noticed in the experimental groups than in the control one.

Previous study are agree in our results by Mahae and Chaiseri (2009) who recorded that the highest significant activity levels of SOD and GPx concentration detected in group supplemented with galanga may be due to the which considers a rich source of antioxidants that lead to the expulsion of toxins and inhibiting free radicals. Also, recent studies and agree with our result by Abdel-Azeem and Basyony (2019) who found that supplementing a diet with Alpinia galanga exetract (AGRE) significantly raised antioxidant capacity, glutathione Stransferase, superoxide dismutase, catalase, and glutathione peroxidase Likewise. Negm and Ragheb (2019) found that supplementing AGRE increased SOD levels while decreasing MDA levels. Also, Al-Mosawy and Khalid (2021) who documented that the highest significant activity level of SOD and GPx and reduced reversed the $\mathrm{H}_{2} \mathrm{O}_{2}$ impacts recorded in group consumed Alpinia galanga extract in quails.

Regarding, the role of zinc, the findings of this study agree with those Boiko et al., (2020) who revealed that increasing glutathione reductase and catalase activity. Also, Mazani et al., (2012) found that Zn supplementation boosted overall antioxidant capacity, glutathione peroxidase, and SOD activity while decreasing MDA levels in the blood serum. On the other hand, Alissa et al., (2009) illustrated that dietary zinc supplementation can modulate SOD activity in rabbits. In addition, Zhao et al., (2014) found that the concentration of SOD was significantly increased in serum of broilers after feeding $\mathrm{nZnO}$. 
Conclusively, it is concluded that rabbit's bucks blood parameters, immunity and oxidative status may be improved with alpinia galanga and zinc supplementation to rations of Californian rabbit bucks.

ACKNOWLEDGEMENT

The authors are thankful to Prof. Dr. Mohamed Abd Aziz El-Sawy, Department of Rabbits Research, A.P.R.I., for reviewing and help in this work.

\section{REFERENCES}

Abdel-Azeem, S.A. and Basyony, M.M. (2019). Some blood biochemical, antioxidant biomarkers, lipid peroxidation, productive performance and carcass traits of broiler chicks supplemented with alpinia galangal rhizomes extract during heat stress Egypt. Poult. Sci., Vol. (39) (II): 345363.

Abdullah, F.; Subramanian, P.; Ibrahim, H.; Abdul- Malek, S.; Lee, G. and Hong, S. (2015). Chemical composition, antifeedant, repellent, and toxicity activities of the rhizomes of galangal, Alpiniagalanga against Asian subterranean termites, Coptotermesgestroi and Coptotermescurvignathus (Isoptera: Rhinotermitidae). Journal of Insect Sci., 16; 15:175.

Ahmed, A.A.W.; Mohammed, A.A. ; Khalid, M.A.l.; Fatma, M.S.; Islam, M.S.; Fahdah, A.A.; Muhammad, M.; Mohamed, H.A.S.; Abdalla, H.H.A.; Mohamed, O.T.; Hazem, G.M.; Mahmoud,S.A.El.; Abdallah, E.M. and Ahmed, E.A. (2020). Combined Supplementation of Nano-Zinc Oxide and Thyme Oil Improves the Nutrient Digestibility and Reproductive Fertility in the Male Californian Rabbits. Animals, 10, 2234; 1-12; doi:10.3390/ani10122234.

Aksu, D.S.; Aksu,T. and Onel, S.E. (2012). Does inclusion at low levels of organically complexed minerals versus inorganic forms create a weakness in performance or antioxidant defense system in broiler diets. Int. J. Poultry Sci., 11: 666- 672.

Alissa, E.M.; Bahijri, S.M.; Lamb, D.J. and Ferns, G.A.A. (2004). The effects of coadministration of dietary copper and zinc supplements on atherosclerosis, antioxidant enzymes and indices of lipid peroxidation in the cholesterol-fed rabbit. Int. J. Exp. Path., 85(5):265-275.

Al-Mosawy, A.M.S. and Khalid, C.K. (2021). The Effect of Alcoholic Extract of Rhizomes of Greater Galangal (L.) on the Serum Antioxidant Enzymes for Japanese Quail During Oxidative Stress Induced by Hydrogen Peroxide. Basrah J. Agric. Sci., 34(1): 171-179. 
IMPACT OF ALPINIA OFFICINARUM AND ZINC ON RABBIT BUCKS 13

Alok, P.J.; Rajesh, S.P.; Santram, L. andAbhay, K.S.P. ( 2012). Immunomodulatory and anti-oxidant potential of Alpiniagalanga Linn. Rhizomes Pharmacognosy Communications; Volume 2:30-37.

Basri, A.M.; Taha, H. and Ahmad, N. (2017). A review on the pharmacological activities and phytochemicals of Alpiniaofficinarum (galangal) extracts derived from bioassay-guided fractionation and isolation. Pharmacognosy Reviews, 11(21): 43-56.

Boiko, O.V.; Honchar, O.F.; Lesyk, Y.V.; Kovalchuk, I.I. and Gutyj, B.V. (2020). Effect of zinc nanoaquacitrate on the biochemical and productive parameters of the organism of rabbits. Regul. Mech. Biosyst., 11(2):243248.

Chouni, A. and Paul, S. (2018). A Review on Phytochemical and Pharmacological Potential of Alpinia galangal. Pharmacognosy Journal, 10 (101): 9-15.

Doumas, B. (1981). Colorimetric method for albumin determination. Clin. Chim. Acta, 31,87-92.

Duncan, D.B. (1955). Multiple ranges and multiple F. test. Biometrics, 11-42.

Ezzat, W.; Habeib, A.A.; Hanan, S.M. andFathey, I.A. (2019). Effect of propolis and zinc methionine supplementation on improvement of productive, reproductive and immunity performance of local developed insash strain under Egyptian summer conditions. Egypt. Poultry Sci., Vol. (39) (I): 253-273.

Fasati, P. and Prencipe, L. (1982). Determination of plasma triglycerides. Clinical. Chem., 28: 2077.

Ganguly, N.K.; Medappa, N. and Srivastava, V.R. (2002). Ginger: its role in enobiotic metabolism. ICMR Bulletin, 33(60): 57-58.

Haase, H.; Mazzatti, D.J.; White, A.; Ibs,K.H.; Engelhardt, G.; Hebel, S.; Powell, J.R. and Rink,L. (2007). Differential gene expression after zinc supplementation and deprivation in human leukocyte subsets. Mol. Med. 13: 362-370.

Haghighian, H.; Haidari, F.; Mohammadi-asl, J. and Dadfar, M. (2015). Randomized, triple-blind, placebocontrolled clinical trial examining the effects of alpha-lipoic acid supplement on the spermatogram and seminal oxidative stress in infertile men. Fertility and Sterility., 104(2): 318-324.

Hassan,F.A.M.; Mohamed, R. and El-Araby, I.E. (2017). Growth Performance, Serum Biochemical, Economic Evaluation and IL6 Gene 
Expression in Growing Rabbits Fed Diets Supplemented with Zinc Nanoparticles. Zagazig Vet. J. Res. Article., 45(3): 238-249.

Ippoushi, K.; Ito, H.; Horie, H. and Azuma, K. (2005). Mechanism of inhibition of peroxynitrite-induced oxidation and nitration by [6]-gingerol. Planta-Medica, 71: 563-566.

Janten, I.; Rafi, A. and Jali, J. (2005). Platelet-activating factor (PAF) receptorbinding antagonist activity of Malaysian medicinal plants. Phytomedicine, 12(6): 88-92.

Kaushik, P.; Kaushik, D.; Yadav, J. and Pahwa, P. (2013). Protective effect of Alpiniagalanga in STZ induced diabetic nephropathy. Pak. J. Biol. Sci., 16: 804-811.

Kim, B.J.; Kim, J.H.; Kim, H.P.; Heo, M.Y. (1997). Biological screening of 100 plant extracts for cosmetic use (II): anti-oxidative activity and free radical scavenging activity. Int. Journal of Cosmet Sci., 19(6):299-307.

Kiuchi, F.; Matsuo, K.; Itano, Y.; Ito, M.; Honda, G.; Qui, TK .and Aoki, T. (2002). Screening of natural medicines used in Vietnam for trypanocidal activity against epimastigotes of Trypanosomacruzi. Natural Medicines, 56(2): 64-68.

Kumar, S. and Alagawadi, K. (2013). Anti-obesity effects of galangin, a pancreatic lipase inhibitor in cafeteria diet fed female rats. Pharm Biol., 51(5): 607-613.

Lagrange, P.H.; Mackaness, G.B. and Miller, T.E. (1974). Potential of T cell mediated immunity by selective suppression of antibody formation with cyclophosphamide. J. Exp. Med., 139: 1529-1539.

Li, M.Z.; Huang, J.T.; Tsai, Y.H.; Mao, S.Y.; Fu, C.M. and Lien, T.F. (2016). Nanosize of zinc oxide and the effects on zinc digestibility, growth performances, immune response and serum parameters of weanling piglets. Anim. Sci. Journal, 87(11): 1379-1385.

Liao, DY.; Chai, YC.; Wang, SH,.;Chen, CW. and Tsai, MS. (2015).

Antioxidant activities and contents of flavonoids and phenolic acids of Talinum triangulare extracts and their immunomodulatory effects. Journal of Food Drug. Anal.; 23: 294-302.

Mahae, N. and Chaiseri, S. (2009). Antioxidant activities and antioxidative components in extracts of Alpiniagalanga (L.) Sw. Kasetsart Journal of Natural Science, 43: 358-369.

Mazani,M.H.; Argani, N.; Rashtchizadeh, Hamdi, A.; Estiar,M.A. and Nezami, N. (2012). Effects of zinc supplementation on antioxidant status 
IMPACT OF ALPINIA OFFICINARUM AND ZINC ON RABBIT BUCKS 15

and lipid peroxidation in hemodialysis patients; Journal of Ren. Nutr., 23(3):180-4. doi: 10.1053/j.jrn.08.012.

Mocchegiani, E.; Corradi, A.; Santarelli, L.; Tibaldi, A.; DeAngelis, E.; Borghetti, P.; Bonomi, A.; Fabris, N. and Cabassi, E. (1998). Zinc, thymic endocrine activity and mitogen responsiveness (PHA) in piglets exposed to maternal aflatoxicosis B1 and G1. Vet. Immunopathol, 62(3):245-260.

N.R.C. (1977). National Research Council. Nutrient Requirements Of Domestic Animals. Nutrients Requirement Of Rabbits. USA. National Academy of Science, Washington, D.C.

Negm, S.H. and Ragheb, E.M. (2019). Effect of (Alpinia officinarum) Hance on Sex Hormones and Certain Biochemical Parameters of Adult Male Experimental Rats. J. of Food and Dairy Sci., Mansoura Univ., Vol 10 (9):315-322.

Rachkeeree, A.; Kantadoung, K.; Suksathan, R.; Puangpradab, R.; Page, P.A. and Sommano, S.R. (2018). Nutritional Compositions and Phytochemical Properties of the Edible Flowers from Selected Zingiberaceae Found in Thailand. Front. Nutr., 01 | https:// doi.org/ 10.3389/fnut.2018.00003

Raviraja, S.G and Monisha, S. (2015). Pharmacology of an Endangered Medicinal Plant Alpiniagalanga. A Review. RJPBCS., 6(1): 499.

Reitman, S. and Frankel, S. (1957). A colorimetric determination of serum AST and ALT enzymes. Amer. J. Clin. Path, 28: 56-58.

Saboo, S.; Chavan, R.; Tapadiya, G. and Khadabadi, S. (2014). An Organized Assessment of Species of Plants of Alpinia Genera, Belonging to Family "Zingiberaceae". American Journal of Ethnomedicine, 1(2): 102-108.

Sanja, J.P.; Ljiljana, M.K.; Nikola, M.P.; Jovanka, D.L.; Olivera, M.Đ.; Bojana, M.K.; Ivana, S.Ĉ. and Marina, V.V. (2015). Effect of synbiotic on growth and antioxidant status of blood in broiler chicken. Food and Feed Research., 42: 163-169.

Sarieh, S.; Javad, S.R.; Farzaneh, M.R.; Mohammad, R.S. and Mohammad, R. (2014). Effects of Aqueous Root Extracts of Anacyclus pyrethrum on Gonadotropins and Testosterone Serum in Adult Male Rats. AJPCT., 2(6): 767-772.

SAS (2002). SAS /STAT guide for personal computer, proprietary software version 9. SAS Institute Inc. Cary, North Carolina, USA. 
Sharma, N.;Kumar, A.; Sharma, P.; Qayumc, A.; Singhc, S.; Dutta, P.; Pauld,S.; Guptae,V.; Vermab, M.; Sattia, N. and Vishwakarmaa, R. (2018). A new clerodanefuranoditerpene glycoside from Tinosporacordifolia triggers autophagy and apoptosis in HCT-116 colon cancer cells. J. of Ethnopharmacology; 211: 295-310.

Terpiłowska, S. and Siwicki, A.K. (2011). The role of selected microelements: selenium, zinc, chromium and iron in immune system. Central-Europ. J. Immunol., 36 (4): 303-307.

William, T.; Friedewald, R.L. and Donald, S.F. (1972). Estimation of the concentration of low-density lipoprotein cholesterolin plasma, without use of the preparative ultracentrifuge. Clinical Cchemistry, Vol. 18, No. 6, ,499-502.

WZeng, L .J.; Zhang, F. Zhang, C .and Liang,W. (2018). Naringenin as a potential immunomodulator in therapeutics. Pharmacol Res; 135: 122-6.

Xu, C.; Huang, Z.; Liu, L.; Luo, C.; Lu, G.; Li, Q. and Gao, X. (2015). Zinc Regulates Lipid Metabolism and MMPs Expression in Lipid Disturbance Rabbits. Biological Trace Element Research, 168 (2): 411-420.

Yatoo, M.I.; Saxena, A.;.Deepa, P.M.; Habeab, B.P.; Devi, S.; Jatav, R.S. and Dimri,U. (2013). Role of Trace elements in animals: A review, Vet. World., 6(12): 963-967.

Zhao, C.Y.; Tan, S.X.; Xiao, X.Y.; Qiu, X.S.; Pan, J.Q. and Tang, Z.X. (2014). Effects of dietary zinc oxide nanoparticles on growth performance and antioxidative status in broilers. Biol Trace Elem Res, 160 (3):361-367.

$$
\begin{aligned}
& \text { تأثير إضافة الخولتجان والزتلك على بعض مقايبس الام وحالة الأكسده }
\end{aligned}
$$

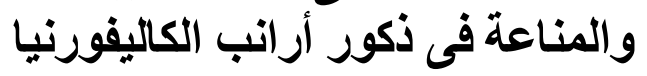

$$
\begin{aligned}
& \text { محمد السيد السبيعى - محمد مصطفى عبد اللاة ـ عادل محمد عيد القمحاوى- } \\
& \text { محمد على عبد العال } \\
& \text { معهد بحوث الانتاج الحيو انى ـ مركز البحوث الزر اعية - وز ارة الزر اعة ـ- مصر. } \\
& \text { أستخدم فى هذه الدر اسة عدد ستة وثلاثون ذكر من سلالة الكاليفورنيا عمر 4-5 أثـهر } \\
& \text { بمتوسط وزن } 2980 \text { × } 30.3 \text { جر ام و تم توزيعها عشو ائيا الى ستة ستة معاملات وبكل وبكل معاملـة }
\end{aligned}
$$


IMPACT OF ALPINIA OFFICINARUM AND ZINC ON RABBIT BUCKS 17

عدد 6 ذكور وذللك بهدف دراسـة تـأثير اسـتخدام الخولنجـان المجفة (AGR) وكبريتـات الزنك على مقاييس الدم وحالة الأكسدة والصفات المناعية لذكور أر انب الكاليفورنيا.

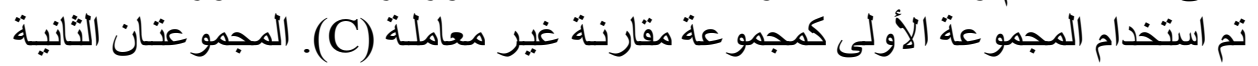

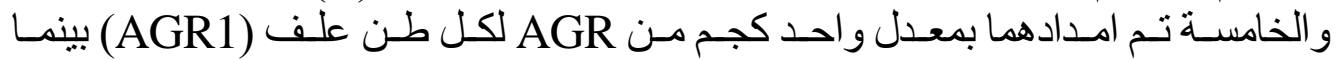

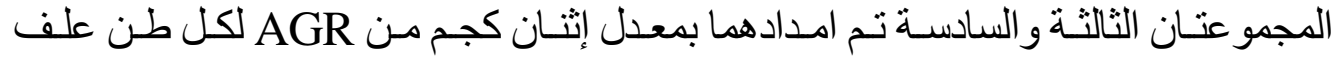
(AGR2)

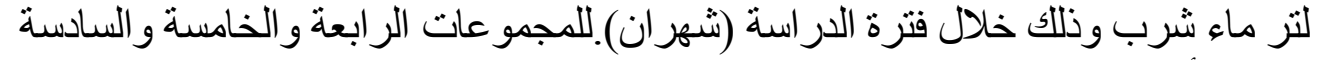

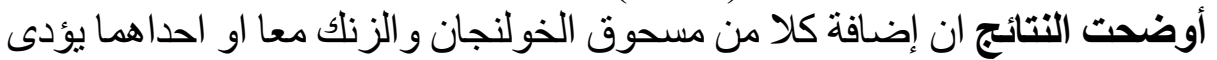

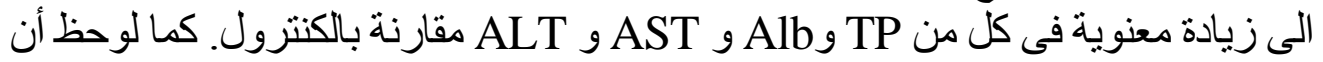

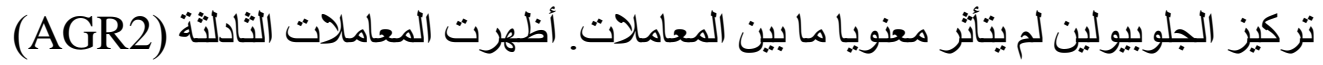

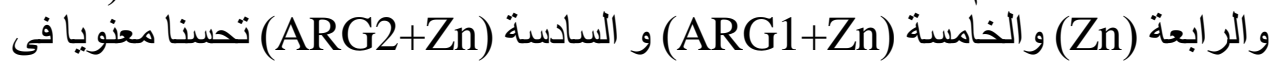

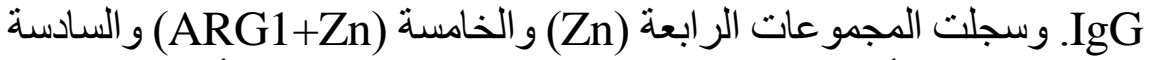

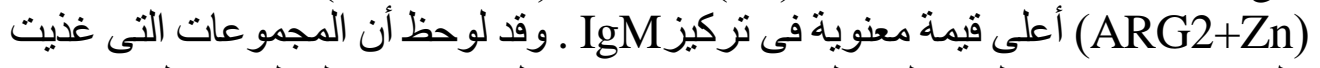

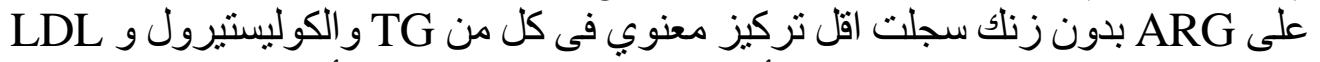

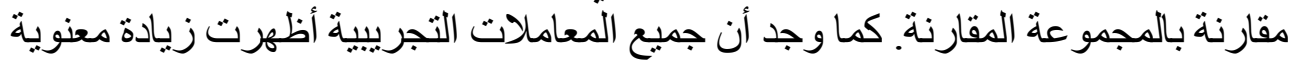

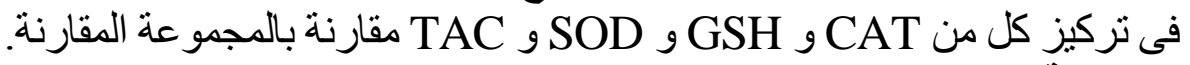
التوصية: ادى استخدام مسحوق نبات الخولنجان الى تحن تحسين الصفات الكيموحيوية للام وحالة الاكسدة و المناعة لذكور ار انب الكاليفورنيا. 